\title{
A Study on the Relationship Between CAPM and China Stock Market
}

\author{
Gao Yan \\ School of Economics and Management \\ Lanzhou Jiaotong University \\ Lanzhou China
}

\author{
Yang Xin \\ Gansu Branch \\ China Development Bank \\ Lanzhou China
}

\begin{abstract}
The Capital Assets Pricing Model (CAPM) has been one of the most important theories in finance, since that was developed by Sharpe and Lintner in1960s. This paper studies the applicability of the CAPM on China stock market, which is an emerging stock market. Firstly the paper presents an outline of China Stock market. Secondly the paper reviews evolution of the CAPM by looking back existent literatures. That includes the studies that challenge it, the studies that against those challenges, and tests of the CAPM in China stock Market. Finally, the finding is that the relationship between expected return and risk is not linearly positive. In addition, there is significant evidence to conclude the existence of other factors differ from $\beta$ that affect expect return. Therefore the conclusion of the paper shows that the CAPM is not applicable in China Stock Market.
\end{abstract}

Keywords-CAPM; China stock Market; Western stock Market

\section{BACKGROUND OF CHINA STOCK MARKET}

China government started to develop organized stock market in 1990s in order to reform from a highly centralized planned economy to a flexible market economy. China stock market consists of two exchange markets. One of them is the Shanghai Stock Exchange (SSE) that was established on 26 November 1990 and started trading on 19 December of the 1990. The SSE is located in the Shanghai. The other one is Shenzhen stock market (SZSE), which was established on 1 December 1990 and started trading on 3 July 1991. SZSE is situated in Shenzhen. The SSE and the SZSE were endued with different characteristics respectively by China government. Most companies listed on the SSE are large and state-owned firms as China government attempts to reinstate Shanghai as influential financial centre in Asia. Consequently, SSE may be sheltered from the fluctuation in the world economy.
Compared with the SSE, companies listed on the SZSE are typically small and export-oriented firms.

Two types of shares are traded on both the SSE and the SZSE. A-shares are denominated in RMB and can only be bought and sold by Chinese citizens. B-shares are denominated in US dollars and can be bought and sold by foreign investors and residents of Hong Kong, Macao and Taiwan. Since March 2001, B shares have been opened to domestic investors holding US dollars. These two types of shares have equivalent voting power and claims on earnings and assets. Obviously, the Ashare market plays the most important role in stock market for domestic investors. By the end of 2017, 3385 domestic companies have issued A-shares in this market and the market value has reached56620 billion RMB. The B-share market was established in 1992 in order to attract foreign investments. The B-share market is unique feature of China stock market and it perfectly reflects the mixed purpose of the Chinese government toward the internationalization of the Chinese stock market. By the end of 2017, only 100 companies had issued B-shares in this market and the market value had reached 182.18 billion RMB.

The period, from 1995 to 2007, is a period of market reform. This period is milestoned by China's entry into the World Trade Organization (WTO) and marked by improvements in regulatory protection of minority shareholders, increases in accounting transparency and audit quality, privatization of state-owned enterprises, and the increase of foreign investor direct investment in the A-share market. The Table I shows the comparison between A-share and B-share in terms of number of listed companies and total market value during of period of 1995-2004 as follows: 
TABLE I NUMBer OF LISTEd COMPANIES AND MARKET VALUE (1995-2004)

\begin{tabular}{|c|c|c|c|c|}
\hline & \multicolumn{2}{|c|}{ A-shares } & \multicolumn{2}{|c|}{ B-shares } \\
\hline & Listed Companies & Market Value(billion) & Listed Companies & Market Value(billion) \\
\hline 1995 & 311 & 331.06 & 70 & 16.37 \\
\hline 1996 & 514 & 944.86 & 85 & 39.4 \\
\hline 1997 & 720 & 1715.42 & 101 & 37.5 \\
\hline 1998 & 825 & 1929.93 & 106 & 20.26 \\
\hline 1999 & 921 & 2616.76 & 108 & 30.35 \\
\hline 2000 & 1010 & 4745.58 & 114 & 63.52 \\
\hline 2001 & 1130 & 4224.56 & 110 & 127.67 \\
\hline 2002 & 1199 & 3752.66 & 111 & 80.26 \\
\hline 2003 & 1261 & 4745.58 & 111 & 93.72 \\
\hline 2004 & 1348 & 3630.94 & 110 & 74.62 \\
\hline
\end{tabular}

Since 1990 SSE was established, China stock market had grown rapidly while it possessed some unique characteristics because of particular system of economy in China. Hu observes that the Chinese stock market is very different from others, especially in terms of the extent of government regulations and investor composition.

First of all, the division between A-shares and B-shares is one of important features of Chinese stock markets which may lead to stocks of same companies were traded in significantly different price. Moreover, China stock market is an inefficient market. The efficient market hypothesis $(\mathrm{EMH})$ that was raised by Fama assumes that stock prices adjust rapidly to the publication of any new information, and thus current prices fully reflect all available information [1].

Ten years ago, the subprime crisis led to a liquidity crisis in the world's major financial markets. China's stock market has also undergone a round of adjustment, but China's economy will continue to grow rapidly, and the super-expected growth of listed companies' performance will also continue. At the same time, the trend of RMB appreciation has not changed, so the overall upward trend of the stock market has not changed. As follows:

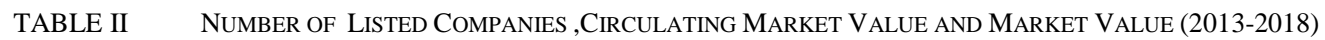

\begin{tabular}{|c|c|c|c|}
\hline & Listed Companies & Circulating Market Value(billion) & Market Value(billion) \\
\hline 2013 & 2489 & 19957.95 & 23907.72 \\
\hline 2014 & 2613 & 31562.43 & 37254.70 \\
\hline 2015 & 2827 & 31792.54 & 53130.42 \\
\hline 2016 & 3,052 & 39326.63 & 50824.51 \\
\hline 2017 & 3485 & 44910.53 & 56747.54 \\
\hline $2018^{\text {a }}$ & 3512 & 44810.22 & Source: http://www.csrc.gov.cn/pub/ \\
a Up to February
\end{tabular}

As an emerging market, which is, has been established only for 28 years, China stock market is not efficient as Western mature stock markets. Then, excessive intervention of Chinese government also is a feature of China stock market. As Jin and Tang claimed, policy factors are the primary reason for market movements in the period from 1992 to 2000 [2]. Last but not least, there is a mass of non-negotiable or non-tradable share, which is owned by state on China stock market.

\section{LITERATURE REVIEW}

\section{A. CAPM and its assumptions}

Sharpe and Lintner developed the Capital Assets Pricing Model (CAPM) in 1960s. Since then it has long been one of most important theories in finance. The CAPM is built based on the model of portfolio choice developed by Harry Markowitz. The portfolio model provides an algebraic condition on asset weights in mean-variance efficient portfolios. Sharpe and Lintner have led to the formulation of the CAPM. This equilibrium theory of the capital market claims that securities should be priced according to their systematic risk or covariance with the market. The formulation is [3]

$$
\mathbf{E}(\mathbf{R} i)=\mathbf{R}_{\mathrm{f}}+\boldsymbol{\beta} \boldsymbol{i}\left(\mathbf{E}\left(\mathbf{R}_{\mathrm{m}}\right)-\mathbf{R}_{\mathrm{f}}\right)
$$

Where,

$\mathbf{E}(\mathbf{R} \boldsymbol{i})=$ the expected return on security $i$ 
$\mathbf{R}_{\mathbf{f}}=$ the risk-free rate of interest available during the period (e.g. Government bond rate)

$\mathbf{E}(\mathbf{R m})=$ the expected return on the market portfolio during the period

\section{$\boldsymbol{\beta} \boldsymbol{i}=$ the systematic risk of security $\boldsymbol{i}$}

The formula show that the relation between expected return on an asset and its $\beta$ (systematic risk) is linear and positive. While the $\beta$ is the covariance of return of stock with the market return divided by the variance of the market return. It represents the sensitivity of the return of single stock to any change of the return of the market portfolio. In other words, a bigger $\beta$ value indicates a high-risk stock; a smaller $\beta$ value indicates a low risk stock. Then following conclusion can be obtained, the risks of single stock which is irrelevant with market risk are useless in asset pricing and the $\beta$ is sole factor to price assets. This is core idea of Sharp-Lintner's CAPM.

The validity of the CAPM is built on the basis of some assumptions and many scholars have explored them. Modigliani, Pogue and Solnik argue that the Sharpe-Lintner CAPM relies on certain assumptions about investor behavior and capital markets [4].

These assumptions are stated as follows:

Assumption A, investors choose their asset portfolios by appraising the expected return and the variance. It means that all investor will only hold a portfolio, which they perceive as being mean-variance efficient.

Assumption B, the market must be perfect market. This assumption implies that all assets are infinitely divisible; there are no transaction costs or taxes, and borrowing and lending rates are equal to each other and the same for all investors. Mertens argues that single investor has no the power to move the market, nor does any particular group of investors. Please note that prices are still determined by the actions of investors, they are the result of the portfolio decisions by all investors not a single investor or a single group of investors.

Assumption C, in order to support CAPM Sharpe and Lintner also assume markets equilibrium that means that supply of assets equals demand. The market portfolio is defined as the portfolio of assets, which are in positive net supply, weighted by their market capitalization. Usually it is assumed that the risk-free instrument is in zero net supply. On the demand side, the net holdings of all investors equal aggregate net demand. Mertens states that the market portfolio is the portfolio of all the efficient portfolios held by the individual investors weighted by their relative wealth in equilibrium market, each investor's net wealth is positive hence the market portfolio is a convex combination of efficient portfolios. The efficient set mathematics implies that such a convex combination is also an efficient portfolio.

\section{B. Empirical Test of the CAPM on Western Market}

\section{1) Early Empirical Tests of the CAPM}

The earliest empirical of test is Sharpe's original work. The author chooses 34 mutual funds from US. Market during 19541963 as research sample. He computes the average return and its standard deviation of every fund and regresses them. The conclusions of his research include following several aspects, a) In the meantime, the return of market portfolio is bigger than return of risk-free assets in US. b) The correlation coefficient of average return and its standard deviation is more than 0.8. c) The relation between risk and return is approximately linear. His study proves evidence for the CAPM.

After Sharpe and Lintner, some researchers conduct their studies to support CAPM. Black, Jensen, and Scholes select all of the stocks on the NYSE during 1931-1965 to form 10 portfolios with different historical beta estimates. They point out that the data was consistent with the predictions of the CAPM, their study prove that the CAPM is an approximation to reality [5].

Following the pioneer work of Black, Jensen, and Scholes, other similar studies show similar results. In research of Fama and MacBeth, they add additional explanatory variables to the cross-sectional regression of expected returns on betas [6]. The result shows that return date from NYSE during 1926-1968 support the CAPM. Blume and Friend's study is also consistent with the CAPM. In short, most of studies follow the CAPM until 1980s.

\section{2) Empirical Tests Which Challenge the CAPM}

The CAPM is a best-known model of risk and return and it is wildly used in both academic and practical purposes but it is not as perfect as the supporters describe. Since 1980s the CAPM was challenged by extensive studies and these studies find that there are some factors other than $\beta$ are more powerful to explain the average return during the 1963-1990 period. Most of them focus on the anomalies of the CAPM such as firm size and book-to-market equity and provide significant evidences which contradict with the central tenet of the Sharpe, Lintner and Black, Jensen and Scholes's CAPM.

Banz's research focuses on the small-firm effect and the author points out that it is better than CAPM to explain the expected return on stock portfolio which is formed according to size or industry [7]. His finding is better to be known as "size effect". And Barry et al. investigate the usefulness of size and book-to-market equity effects across 35 emerging equity markets over the period of 1985-2000. [8] They find a strong positive relationship between book-to-market equity and average stock returns and a negative relationship between firm size and average stock returns.

The most damaging challenge is Fama and French's study. The study takes stock on US. Stock market include the NYSE, the National Association of Securities Dealers Automated Quotations (NASDAQ) and American Stock Exchange (AMEX) as sample to estimates the relation over period of 1962-1989. Fama and French concludes that the CAPM has no power to explain the cross-section of average returns on assets sorted by size and book-to-market equity ratios for period of 1962-1989. Furthermore, they also argue 
that CAPM has never been tested, and prospects for testing it are not good because the set of left-hand-side assets does not include all marketable assets, and data for the true market portfolio of all assets are likely beyond reach [9].

\section{3) Literatures which against the challenges}

Although the CAPM of Sharpe and Lintner is doubted by many people and some alternative model such as Fama and French's three-factor model and Ross's arbitrage pricing theory seem to find more factors to explain the cross-section of average return, the CAPM still have numerous supporters, the debate has never stopped. To response the studies that challenge the CAPM, Black argue that firm size and book-tomarket equity anomalies are due to data mining. The person believes that the size effect of Banz is sample-specific, which means the result of Banz's study lies on the specific sample period and it can not be proved with other data. The study of Fama and French is oppugned due to the data and sample period as well. Kothari, Shanken, and Sloan point out that the data in Fama and French's study are too noisy to invalidate the CAPM. They re-test the cross-section of average return with different sample chosen from longer test period. Then they find that the relation between average return and book-to-market equity is much weaker than that in Fama and French's study in period of 1947-1987. Moreover, they gain same result in period of 1963-1990, which is identical with Fama, and French's test period.

\section{CAPM IN CHINA}

The CAPM has been introduced into China almost thirty years so there are very few literatures regarding to testing the CAPM in China stock Market. In these few literatures, there are mixed views. Yang argues that the relationship between return and risk not as what CAPM expected in Shanghai stock market. The system risk is not the only factor in determining stock return and there are other factors in determination of stock returns, including firm size, ratio of negotiable share volume to total share volume, return on equity and turnover of trading.

Later, Su's research tests the CAPM on China stock market during 1994-1998. His results show that firm size does not influence the cross-section of average return [10]. Sun and Tong find some empirical support for both a traditional CAPM and the Intertemporal CAPM when controlling for market segmentation [11]. Drew, Naughton and Veeraragaghavan test the multifactor model on Shanghai Stock Exchange market factor alone is not sufficient to describe the cross-section of average stock returns in China [12].

The study from Mao, the author chooses all available stocks in Shenzhen Stock Exchange from 1997 to 2001 as sample to test the CAPM. The author finds that the relation between return and $\beta$ is negatively linear. [13] For China stock market, most of research about the CAPM is carried out with data up to 2015 .

Zheng and Xu's work selects 20 stocks from SSE A-share as research samples and verifies the applicability of CAPM from January 2010 to May 2015 by using the monthly return data. They conclude that CAPM model is feebly applied in Shanghai A-shares. [14] Wu's research points out that SZSE stock portfolio is basically the same as individual one, but the $\beta$-value is more appreciated by the risk of stock portfolio [15].

\section{CONCLUSION}

Since the naissance of the capital asset pricing model (CAPM) that developed by Sharpe and Lintner, it has been researched and tested by many scholars. The paper reviews evolution of the CAPM by looking back existent literatures which include the studies that support the CAPM, studies that challenge it, studies that against those challenges, and tests of the CAPM in western market and China stock Market.

Base on the literature review and existent tests, the paper selected 44 stocks from both SSE and SZSE as a sample to observe their market data in last ten years. Conclusions have been obtained. First of all, the time value of stocks is negative. It indicates that investors focus on return more than on time value of capital, and most investors are speculative investors on China stock market. Secondly, the relation between expected return of stock and risk is not linearly positive. The $\beta$ is positive but insignificant; it means that the relation between expected return of stock and risk is positive but linearly positive which the CAPM expected. Thirdly, there are other factors differ to $\beta$ affect expected return of stock, it means that systematic risk affect expected return in some sense but it is not sole factor.

Above conclusions are hardly surprising because the CAPM is built on the basis of some assumptions about the stock market. The CAPM assumes that a) investors choose their asset portfolios by appraising the expected return and the variance.b) the market must be perfect market. c) the market is equilibrium markets. These assumptions do not apply in China stock market. For instance, China stock market is not perfect market, the cost of transaction in China stock market is much higher than western mature market. Moreover, due to the great amount of non-negotiable stock it is difficult to find out an appropriate index as proxy of market portfolio. All above reasons result the failure of the CAPM on China stock market.

All in all, because China stock market is still emerging and immature market, the CAPM is not applicable in China stock market of today. 


\section{REFERENCES}

[1] Fama, Fugene. F. (1970) "Efficient capital markets: a review of theory and empirical work" Journal of Finance, vol.25, pp.383-417.

[2] Jin, X. B. and Tang, L. M. (2001) "On the game between government policy and stock investors" Working Paper of Haitong Security Company.

[3] Sharpe, William F. (1964) "Capital asset prices: A theory of market equilibrium under conditions of risk" Journal of Finance, vol. 19, pp.425-42, September.

[4] Modigliani, F., Pogue, G. A. and Solnik, B. H. (1973) "A test of the capital asset pricing model on European stock markets", July.

[5] Black, Fischer, Jensen, Michael C. and Scholes, Myron (1972) "The capital asset pricing model: Some empirical tests" Studies in the Theory of Capital Markets, ed. Michael Jensen, pp.79-121. New York: Praeger.

[6] Fama, Eugene F., and MacBeth, James D. (1973) "Risk, return and equilibrium: Empirical tests" Journal of Political Economy, vol. 81, pp.607-36, May-June.

[7] Banz, Rolf W. (1981) "The Relationship between return and market value of common stocks" Journal Financial Econ, vol. 9, pp.3-18, March.

[8] Barry, C. B., Goldreyer, E., Lockwood, L. and Rodriguez, M. (2002) "Robustness of size and value effects in emerging equity markets, 19852000.” Emerging Markets Revie, vol.1:3, pp.1-30.

[9] Fama, Eugene F., and French, Kenneth R. (1993) "Common risk factors in the returns on bonds and stocks" Journal of Financial Economics, vol. 33 , pp.3-56, February.

[10] $\mathrm{Su}, \mathrm{D}$. (2000) "Asset pricing in a segmented emerging market" journal of Applied Economics, vol. 3, pp.387.

[11] Sun, Q. and Tong, W. (2000) "The effect of market segmentation on stock prices: The China syndrome", Journal of Banking and Finance, vol. 24, pp.1875-902.

[12] Drew, M. E., Naughton, T. and Veeraraghavan, M. (2003) "Firm size, book-to-market equity and security returns: evidence from the shanghai stock exchange" Australian Journal of management, vol. 28:2, September.

[13] Mao, J. (2004) "Empirical test of the CAPM on Shenzhen Stock Exchange" Academic Journal of Jimei University, vol. 7:3, September.

[14] Zheng, W. and Xu, Y. (2015) "An Empirical Study on CAPM Based on Shanghai A-Share Market" Journal of Guizhou Commercial College, vol. 28, No. 4, pp. 5, Dec. (In Chinese)

[15] Wu, Yudong (2011) "Empirical study of CAMP model based on Shenzhen stock market" Journal of Harbin University of Commerce, vol. 27, No. 2, pp.182., Apr. (In Chinese) 